\title{
Sexual Behavior for HIV Prevention among Men who Have Sex with Men in Surakarta
}

\author{
Latifah Nur Alifia'), Hermanu Joebagio²), Bhisma Murti1) \\ 1)Masters Program in Public Health, Universitas Sebelas Maret \\ 2)Faculty of Social an Political Sciences, Universitas Sebelas Maret
}

\begin{abstract}
Background: To date HIV/AIDS is still a serious global health problem with an ever increasing incidence. HIV risk in men who have sex with men (MSM) is 27 times greater than in the general population. This study aimed to analyze the sexual behavior for HIV prevention among MSM in Surakarta using Health Belief Model (HBM).

Subjects and Method: This was a qualitative analytical study with a phenomenology approach. It was carried out in Surakarta Mahardhika Style Community, Central Java. The key informants in this study were the Chairperson of the Gaya Mahardhika Community, with their members as the main informants. The supporting informants consisted of health personnel from the Prevention and Control Program at the City Health Office, and the Surakarta City AIDS Commission Informants were selected for this study by purposive sampling. The data were collected by in-depth interview, non-participatory observation, and document observation. The data were analyzed by the method of Miles and Huberman.

Results: MSM communities in Surakarta understood the concept of HIV/AIDS and knew how to prevent it. But in the reality, the prevention behavior has not really been done as evidenced by all the main informants having more than one partner. Nevertheless, all informants stated that they always used condoms and always checked voluntary counselling test (VCT) regularly. MSM communities consider themselves at risk, believe that HIV/AIDS is a dangerous disease, feel the benefits of HIV/AIDS prevention measures carried out. The obstacles faced are lack of comfort when using condoms and difficulties to be loyal to one partner. They feel the importance of HIV/AIDS preventive behavior. They are sure to be able to implement HIV/AIDS preventive behavior.

Conclusion: Knowledge of HIV/AIDS risk factors is important. The HIV/AIDS preventive behavior applied by MSM is influenced by knowledge, perceived severity, perceived vulnerability, perceived benefit, perceived barrier, cues to action, and self-efficacy.
\end{abstract}

Keywords: HIV prevention, men who have sex with men, Health Belief Model

\section{Correspondence:}

Latifah Nur Alifia. Masters Program in Public Health, Universitas Sebelas Maret. Jl. Ir. Sutami No. 36 A, Surakarta, Central Java 57126, Indonesia. Email: Latifahnuralifia@gmail.com.

Mobile: 08562623045 .

\begin{tabular}{l}
\hline BACKGROUND \\
\hline Since the beginning of the discovery of \\
Human Immunodeficiency Virus (HIV) and \\
Acquired Immune Deficiency Syndrome \\
(AIDS) in humans in the 1920s today, HIV/ \\
AIDS is still a serious global health problem \\
(Avert, 2018; UNAIDS, 2018). HIV/ AIDS \\
infection is not only a health problem, but \\
also a problem in social and economic
\end{tabular}

\section{BACKGROUND}

Since the beginning of the discovery of Human Immunodeficiency Virus (HIV) and Acquired Immune Deficiency Syndrome (AIDS) in humans in the 1920 s today, HIV/ AIDS is still a serious global health problem infection is not only a health problem, but also a problem in social and economic development. Poverty is increasing in many countries because households lose one or more breadwinners because of HIV / AIDS, public services and private companies are affected by HIV / AIDS related diseases and HIV/AIDS deaths occur among their workforce (WHO, 2017).

Despite the progress in understanding the knowledge of HIV/AIDS and its pre- 
vention, new cases of HIV / AIDS are still being discovered. Global data says that HIV sufferers in 2018 reach 37 million people. Some 940,000 people die of HIV in 2017 (WHO, 2018). More than $95 \%$ of HIV infections are in developing countries. One of the countries in Southeast Asia with a high HIV burden is Indonesia (WHO, 2010). The number of people with HIV in Indonesia tends to increase from 2006 (7,195 cases) to 2016 ( 41,250 cases). In 2016, until 2017, the number of HIV cases decreased, from 41,250 people to 33,660 people. Despite the decline, the figure is still relatively high. At the same time, the number of people with AIDS also increased slowly, namely 3,680 cases in 2006 to 7,491 cases in 2016 (Ministry of Health, 2018).

Surakarta is the city with the highest number of HIV cases in Central Java (KPA Central Java, 2018). In 2017, in Surakarta, there were 118 new cases of HIV consisting of HIV 57 people and AIDS 61 people. The total number of cases of HIV/AIDS in Surakarta since 2004 was 595 cases (23\% of the estimated number of cases in Surakarta amounting to 2,620 cases). The findings have not matched the estimates of existing patients. The case of HIV/AIDS is an iceberg phenomenon, meaning the reported cases are only a small number of cases in the community. The proportion of HIV in men is higher than that of women which is $59.65 \%$ male and $40.35 \%$ female. Likewise with AIDS in male patients $72.13 \%$ and women $27.87 \%$. The high number of HIV / AIDS cases in men is caused, among other things, by the presence of male sex groups with men (MSM) who tend to increase. Sexual activity of MSM is very vulnerable to the transmission of the HIV virus. (Surakarta City Health Office, 2018).

The data show that $47 \%$ of new HIV cases occur in key populations, one of which is MSM (UNAIDS, 2018). The global prevalence of HIV in MSM is 19 times greater than in the general population, and HIV risk in MSM is 27 times greater than in the general population (UNAIDS, 2018; WHO, 2017). The Health Belief Model (HBM) states that people will take preventive behavior if they feel vulnerable to health conditions, believe in the seriousness of the disease, feel that barriers to preventive behavior are more difficult than the benefits of preventive behavior, self-efficacy, and signs for act (Murti, 2018).

\section{SUBJECTS AND METHOD}

This was a qualitative study using a phenomenological approach. This study aimed to explore information about the factors influenced HIV/AIDS prevention in MSM at Gaya Mahardika Community, Surakarta, Central Java, using Health Belief Model.

This study used a purposive sampling technique. The key informants were the Chairperson of the Gaya Mahardhika Community, with their members as the main informants, and supporting informants consisting of health workers, the Prevention and Prevention Program (P2P) Health Office and the Secretary of the Jakarta City AIDS Commission.

The data are collected using in-depth interviews, non-participatory observation, and document observation. The data collection tools consist of interview guidelines, recorders, stationery, laptops, and cameras. The data were analyzed by the method of Miles and Huberman.

RESULTS
The pattern of sexual behavior
After in-depth interviews and observations,
researchers identified sexual behavior from
each of the main informants, such as the
number of current partners, types of sexual
activity, and behavior of condom use.


Identifying the number of partners and the type of sexual activity is an important part because it can affect variables and increase the risk of HIV.

All informants in this study were aware of their sexual orientation since elementary school, but began to be sexually active since junior high school. Now, almost all informants have more than one sexual partner and all of them are male. One informant said that he once had a female partner, but this was done only to cover up his identity as an MSM (homosexual). Sexual patterns carried out by informants are not much different from each other, namely beginning with massaging, kissing, oral sex, anal sex, and rimming. One informant also stated that he had once been a "cat". All informants stated that they always use condoms when having sex. One informant said he always carried condoms stored in his wallet, seat or motorcycle dashboard. Condoms are one of the effective ways to prevent HIV/AIDS (WHO, 2013).

\section{Knowledge and attitude toward HIV/AIDS}

The author identified the level of understanding of the informant about the general concept of HIV/AIDS which included understanding, causes, symptoms caused, prevention, and also sources of information. Karki (2014) states that MSM knowledge and attitudes have a relation with HIV/AIDS prevention practices. With the existence of good knowledge about HIV, MSM are expected to be better at taking HIV/AIDS prevention measures.

Based on this research, MSM have good knowledge about HIV/AIDS. They can explain the concept of HIV/AIDS, causes, signs and symptoms, modes of transmission, and HIV/AIDS prevention behaviors. The source of information is counseling and socialization that is often held by the
Mahardhika Style Community as quoted by the Chairperson of the Mahardhika style Community presented as follows:

"Every year we make annual plans, annual activities, one of which provides socialization, education, related to health, both in the community and non-community "(Chair of the Community, Mahardhika Gaya (K1), December o5 2018).

The statement is in line with the statement given by the informant

"From Gaya Mahardhika, from friends, and from some counseling" (A1, o7 December 2018).

All informants were aware of the importance of HIV/AIDS prevention behaviors, and were also concerned about contracting HIV/AIDS if they did not take preventive behavior. Their concerns are caused by a lack of activity and the need to take ARV drugs for life after being infected with HIV. The knowledge of this problem still does not encourage them to take optimal HIV/AIDS prevention measures. All informants stated that the behavior of HIV/AIDS prevention were carried out, namely always using condoms and routinely conducting VCT examinations, but almost all informants stated that they had more than one sexual partner.

\section{Health Belief Analysis Model in HIV / AIDS prevention behavior in MSM Community}

\section{a. The perception of vulnerability}

In this aspect, the researcher identified the perceptions of informants about the vulnerability to the risk of contracting HIV/ AIDS. Almost all informants thought that they were at risk of contracting HIV/AID. This opinion was supported by the Chairperson of the Surakarta City AIDS Commission (KPA) which stated that MSM were very vulnerable to HIV/AIDS transmission, because MSM were always related to sex, some MSM even became sex workers at 
night. In addition, the Head of Disease Control and Environmental Health (P2PL) states that MSM are vulnerable to HIV / AIDS transmission, this vulnerability is related to risky sexual behavior carried out by MSM such as anal sex, and unprotected oral sex.

"Possibly vulnerable, because I used to work as 'cat' or male sex worker" (A3, o7 of December 2018).

However, the informant (A2) argued that his sexual orientation did not cause him to be vulnerable to HIV. What makes it vulnerable is the sexual behavior.

"All people are vulnerable to contracting if they carry out risky activities that result in HIV infection. If I do not have sexual activities that do not use condoms, $I$ will not get infected. But if I am sexually active, and use a syringe, maybe I will get infected" (A2, o7 December 2018).

This opinion is in line with the opinion of the Chairperson of the Gaya Mahardhika Community.

"If you want to say that LSL community is vulnerable, it also means that all people who have a reputation for being insecure in the sense that they are mutually changeable, don't use condoms in their activities, all of them will still be at risk. Yes that was if you want to say risk, all risk depends on their behavior "(Chair of the Gaya Mahardhika Community (K1), December 05, 2018).

\section{b. The Perception of Severity}

In this aspect, the researcher identified the perceptions of informants about the severity that occurred if they did not take HIV/ AIDS prevention measures. All informants were aware of the severity of what would happen if they did not take HIV / AIDS prevention measures.

"Yes, I was infected, I was affected by myself, I was automatically exposed to
$H I V$, taking ARV drugs for life "(A2, December 7, 2018).

But the KPA Secretary of Surakarta stated otherwise. The incidence of HIV / AIDS in MSM is no longer a severity, because there is currently a cure for HIV / AIDS, namely antiretroviral (ARV).

"HIV is not the ending, we can still be healthy because there is a cure. The medicine is ARV "(Secretary of KPA (K2), December 11, 2018).

This opinion is contrary to the opinion expressed by health center health workers (K3), that HIV / AIDS is a severe disease because there is no drug that can really cure people affected by the HIV virus. ARVs are only drugs to suppress the HIV virus rather than eliminate the virus.

\section{c. The Perception of Benefits}

The researcher identified informants about the perceived benefits of HIV / AIDS prevention measures. All informants were aware of the benefits of HIV / AIDS prevention measures that they did.

"The benefits are many, so that I avoid HIV / AIDS. Yes, later we can know we have HIV or not. Later, if you don't get it, it's good, looking for a wife becomes easy (laugh) "(A1, December 7, 2018).

"There are so many benefits. One, we know about reproductive health and HIV / AIDS. Second, we can avoid the HIV. Every one of us is exposed to HIV, we already know what to do, where to treat it, who is accompanied, who is asking for help, and who is directly on ARV treatment "(A2, December 7, 2018)

This is in line with the statement from the Chairperson of the Mahardhika Style Community (K1). That there are so many benefits from HIV/AIDS prevention measures, one of which is the trend of developing HIV/AIDS cases is not high. 


\section{d. The Perception of Barrier}

Some informants stated that there were obstacles in the implementation of HIV / AIDS prevention. One informant (A1) stated that he had an obstacle that originated from within himself.

"Yes there are, bro, maybe if you are in a hurry. Hurrying for lust for example, you can forget and don't use condoms. Yes, even though it's not good (using condoms), but rather than getting sick, it's not more pleasant "(A1, December 7, 2018).

Another informant (A2) stated that there were obstacles originating from health workers.

“.....But if health personnel are new, they have never been visited by a VCT test they sometimes discriminate about religion. That is what makes some of us don't want to see health personnel"(A2, December 7, 2018).

The KPA Secretary (K2) added that if one of the barriers for MSM in implementing HIV/AIDS prevention behaviors is love and mutual trust, so that they no longer think as they should.

\section{e. Cues to Act}

The signal to act refers to Informants A1 and A3 stating that they were encouraged to take HIV/AIDS prevention measures after joining the Mahardhika Style Community. In other words the encouragement comes from the Community.

"Yes from this community, (Gaya Mahardhika Community), I know the information about HIV/AIDS. After knowing it, I behave carefully" (A1, 07 December 2018).

In addition, informant A2 stated that what motivates him to always be healthy is himself and his lover. He stated that role models who encourage healthy behavior is his lover.

"(which encourages) The first one is myself, the second one is the partner, and for the health of the people around us that we love..... Yen panutan yo pacar sek to mbak" (A3, o7 December 2018).

\section{f. Self-Efficacy}

All informants believed that they were able to implement HIV / AIDS prevention behaviors. Good knowledge about HIV / AIDS and how to prevent it makee A1 believe that it is capable of implementing HIV / AIDS prevention.

"Sure. Because I know what prevention, transmission and HIV / AIDS is. At least I already know the background of precautionary measures. So I am confident in myself "(A1, December 7, 2018).

Another informant (A2) said that he believed he was able to apply HIV / AIDS prevention behavior because it was a form of his responsibility for his health.

"Very sure, Ms. Because if it's not from yourself, who else can prevent it? "(A2, December 7, 2018).

\section{DISCUSSIONS}

LSL is an absorption from Men who have Sex with Men (MSM) (Departemen of Health and Human Services, 2018). MSM refer to all men of all ages who engaged in sexual and/or romantic relationships with other men regardless of their sexual identity and sexual orientation (WHO, 2015). According to the Centers for Disease Control and Prevention (CDC) surveillance system, the so-called MSM were gay and bisexual men (CDC, 2018). MSM entered into the key population. According to WHO (2015), key populations were defined groups because high risk behaviors were associated with an increased risk of HIV. MSM often have legal and social problems that increase vulnerability to HIV/AIDS. The presence of social homophobia and internalization, lack of sex education, and the difficulty of accessing HIV test have an effect on risk behaviors of MSM (Burch et 
al., 2018). Young MSM were more vulnerable than older MSM for the effects of homophobia. Homophobia in this context was discrimination of bullying, abuse, family rejection, social exclusion, violence, criminalization, and stigmatization (WHO, 2015). HIV risk in MSM was 27 times greater than in the general population (UNAIDS, 2018). Referring to the term MSM, sexual activities and other activities that can increase the risk must be included. HIV risk-related behavior in the MSM group according to WHO (2010) included MSM who have multiple sexual partners (male or female), did not use condoms during sexual activity, inconsistent condom use, lack of lubricant use, the use of needles and drugs. HIV transmission through unprotected anal sex was 18 times greater than through a vagina without a condom (WHO, 2015). HIV risk behavior in the MSM population was the main concern being studied in several countries. Appropriate and rapid responses at the national and regional levels would be very important to prevent an increase in HIV infection rates in the MSM population (WHO, 2010).

Geary et al., (2018) stated that sexual orientation included three dimensions: sexual identity, attraction, and behavior. MSM were minorities and tend to cover up their identities (UNAIDS, 2018; WHO, 2010). The National Law of the Republic of Indonesia generally did not recognize or support LGBT rights, there were no special anti-discrimination laws related to sexual orientation or gender identity (SOGI). Discrimination against LGBT occurred in almost all sectors. MSM tend to avoid discrimination by being introvert (UNDP and USAID, 2014). Some informants in this study cannot show their sexual orientation to the community and their families.

The sexual behavior, knowledge, attitude, and behavior of HIV/AIDS prevention in MSM in Surakarta were explained in the following descriptions:

Human Immunodeficiency Virus (HIV) was a type of virus that attacked/ infected the body's immune system cells, which caused immune deficiency or immune deficiency (Ministry of Health, 2014; WHO, 2017). Whereas Acquired Immune Deficiency Syndrome (AIDS) was a set of symptoms of a disease that arised due to immune deficiency (KPAN, 2010). AIDS was caused by the HIV virus. As a result of decreasing the body's resistance to someone, then the person was very susceptible to disease. This understanding was in line with the statement of the main informant. Informants can also mention ways of transmission, prevention, and signs of symptoms of HIV/AIDS. Therefore, in general, informants' knowledge about the concept of HIV/AIDS can be categorized quite well. However, this knowledge has not been fully followed by optimal HIV/AIDS prevention behavior. All informants stated that they had consistently used condoms and routinely conducted VCT examinations, however, they had more than one sexual partner. Two of the three key informants stated that they had more than one sexual partner. Murti (2018) stated that there were six stages in behavior change namely prereflection, contemplation, preparation, action, maintenance, and termination. In this study, the behavior of condom use and routine VCT checks on informants had reached the termination stage. The informant did not wish to return to the old unhealthy behavior and the informant was very confident in his ability to consistently use condoms and routinely conduct VCT examinations. Regarding the behavior of having more than one partner, two per three informants in this study were still in the stage of reflection. The informant knew that one of the behaviors to prevent HIV/AIDS 
was to be loyal to one partner, but still not committed to make behavioral changes.

Understanding related to health information was obtained by informants from counseling and training held by the Gaya Mahardhika Community and informants accessing independently about HIV/ AIDS. Informants' understanding of the concept of HIV/AIDS was followed by attitude toward HIV/AIDS, almost all informants expressed concern about the dangers of HIV/AIDS which could affect all sectors of life. A positive attitude was also shown by informants regarding the behavior of HIV/ AIDS prevention. All informants considered that HIV/AIDS prevention behavior was important. All informants admitted they were sexually active with their partner. The pattern of sexual behavior in all informants was almost the same such as kissing, doing sexual penetration through the anus (anal sex), providing sexual stimulation to the partner by using the tongue or mouth which commonly called as oral sex. The type of oral sex performed by informants was penis stimulation (fellatio) and stimulation of the partner's anus (rimming or analingus). One informant stated that once a month, he and his partner planned for honey moon or go somewhere to date or have sex.

Judging from sexual activity, there were several things that need special attention, especially health problems that might arise. First, oral sex can transmit oral, respiratory, and genital pathogens. Oralgenital contact can transmit a number of sexually transmitted infections including herpes, gonorrhea, and HIV. The more exposed to body fluids, the greater the risk of infection. Various channels in the oral cavity that function as the entry gate for infection from the oral cavity into the bloodstream including open wounds, abrasions, or inflammation of bleeding gums (gingivitis, periodontitis) in the mouth, and the virus can enter the systemic (Saini et al., 2010). Although oral sex could carry a lower risk of HIV transmission than other types of sex, repeated exposure to safety can increase the risk of transmission (CDC, 2018). Cornelisse at al., (2018) in her study stated that the risk of orofaringetal gonorrhea was 2 times greater in men who kissed and other oral sex practices.

Second, inserting the penis into the anus (anal sex) was a high risk sexual behavior for HIV transmission. The risk of HIV transmission through anal sex was higher than vaginal sex. Most men who contracted to HIV was through anal sex. In addition, individuals can be exposed to other sexually transmitted diseases such as chlamydia, gonorrhea, hepatitis, various parasites, and bacteria that could be transmitted through feces due to unprotected anal sex. Even if they use a condom, some sexually transmitted diseases can be transmitted through skin to skin contact (such as syphilis or herpes). (CDC, 2018). Ong et al., (2018) stated that MSM have a high risk of anal cancer, this was caused by sexual behavior (anal sex). During anal sex, couples who insert the penis were called insertive (or top) partner, and partners who received the penis were called receptive (or bots) partner (CDC, 2018).

In this study, the researcher discussed about individual perceptions of HIV/AIDS prevention behaviors with the Health Belief Model (HBM) analysis approach which included perceived susceptibility, perceived severity, perceived benefits, perceived barriers, cues to action, and self-efficacy. HBM was a psychological theory that explained and predicted health behavior by focusing on individual beliefs about health and health behavior (Murti, 2018).

The informant's personal perception was related to susceptibility to HIV/AIDS 
Journal of Epidemiology and Public Health 2018, 3(3): 179-191

https://doi.org/10.26911/thejhpb.2018.03.03.05

transmission. Two informants stated that they were vulnerable to be contracted by HIV/AIDS because of sexual behavior. However, one of the informants stated that he was not susceptible to be contracted by HIV/AIDS because he always applied HIV prevention behaviors. This proved that informants have a strong perception of susceptibility to HIV/AIDS. Khumsaen and Stephenson (2017) stated that the higher the level of HIV/AIDS vulnerability felt by MSM, the higher their behavior in HIV/ AIDS prevention. Good knowledge about the concept of HIV/AIDS was the main reason for the high perceived susceptibility of the informants. Because the informant knew the transmission of HIV through body fluids and perceived susceptibility which encouraged the informants to always use condoms when having sexual activity. In addition, to ensure their health conditions, all informants conducted routine VCT checks in every three months.

$\mathrm{Li}$ et al., (2016) stated that low perceived susceptibility of HIV can be a strong reason for high-risk behavior by MSM. This was in line with the results of a study conducted by Raymond et al., (2017) which stated that MSM populations have a high HIV burden. The high risk of HIV in MSM was related to risky behaviors which include having multiple sexual partners (either regular or paid partners, or paying), inconsistent condom and lubricant use, alcohol and drug consumption (WHO, 2010). Even though routine condom use and VCT examination behaviors have been applied, the risk behavior of MSM identified in this study was that almost all informants have more than one sexual partner. Garcia et al., (2016) stated that the high level of multiple sexual partnerships among MSM became a supporter of HIV transmission to MSM. Having sex with multiple partners increased the risk of sexually transmitted diseases transmission including HIV (Chittamuru et al., 2018).

Next was related to perceived severity. Perception of severity referred to a person's subjective assessment of the severity of a disease or health problem, as well as the potential consequences, if it was not prevented or left untreated (Murti, 2018). The lower the perceived severity, the lower their behavior in the prevention of HIV/ AIDS, (Khumsaen and Stepherson, 2017). In this study, the informant stated that HIV was a dangerous, deadly virus, and there was no cure for it.

"if I did not do HIV prevention, maybe I have been contracting to HIV and take ARV for my entire life" (A3, December 7th, 2018).

Another perceived severity was the stigma about HIV and MSM. Li et al., (2016) stated that the perception of HIV severity was not only influenced by disease resistance, but also by the stigmatization of HIV and homosexuality. One informant said that there were many people who considered that HIV was the end of everything, they experienced rejection from within and also high social stigma. A study done by Dubov et al. (2018) stated that MSM with HIV got stigma in the form of labeling, stereotyping, and rejection. Labeling was a strong mechanism in stigma. Labeling has a detrimental effect because people can refuse HIV treatment to avoid being labeled as sex sellers or "cats". While stereotypes as other manifestations of stigma, involved assumptions about free association, unprotected sex, or sex workers. Many MSM experienced rejection in dating applications and even in their relationships when they revealed the use of drugs for HIV.

The next aspect was the perception of benefits. Perceived benefit referred to someone's judgment about value or selfefficacy in conducting healthy behaviors to 
reduce disease risk (Murti, 2018). All informants in this study agreed that the behavior of HIV/AIDS prevention was important and useful. The informant stated that so far, he felt the benefits of the behavior of condom use and routine VCT checks. This was in line with Murti (2018), who stated that if a person believed that a behavior would effectively reduce his vulnerability to experience an illness, then the person was more likely to conduct healthy behavior. Setyabakti (2016) stated that MSM were able to prevent and felt protected when they use condoms during sexual activity. Meanwhile, Fauk et al., (2018) stated that the factors that influenced MSM intention to participate in VCT and access free condoms were positive attitudes including MSM perceptions and knowledge of HV infection, the benefits of attending VCT and accessing condoms, perceived social support or pressure, time and finance. Factors related to the health of sexual behavior among MSM were complex, and preventive pressures need to be adjusted appropriately (Johanson et al., 2018).

Perceived barriers referred to subjective judgments that included a person's perception of problems/obstacles to change his behavior (Murti, 2018). In this study, the informant (A1) stated that the obstacles faced in implementing HIV/AIDS prevention behaviors came from within themselves, which was when they were in a hurry, so they did not have time to use condoms and felt discomfort when using condoms. Another informant (A2) said that the obstacles came from the stigma that came from health personnels when conducting health checks, especially health personnels who were less experienced in dealing with MSM patients. All informants in this study had the same view that MSM were included in the risky group. The similar thing was stated by the Head of
Surakarta City's Disease Control and Environmental Health Division, Health Officer, and KPA Secretary of Surakarta City. Obstacles in the prevention of HIV/AIDS was one of the focus of activities which shown by the collaboration between KPA, the Health Office and the Gaya Mahardhika Community in the implementation of the mobile VCT program for MSM communities. In addition, the availability of condoms was no longer an obstacle because condoms are available at the Mahardhika Gaya Community and all community members can get them for free. The most influential factors of condoms and lubricants in MSM in Surakarta were attitude and knowledge (Wardhani et al., 2015). A study done by Siegler et al., (2014) stated that factors that influence the decision to use condoms were behavior, beliefs, motivation, and interpersonal factors. What was meant by behavior in this case included the availability of condoms, alcohol consumption, petroleum-based lubricants and condom failure. Beliefs and motivations included high levels of self-esteem to implement protective behaviors, condoms reduced pain in the anus, and condoms reduced pleasure. Whereas the definition of interpersonal factors was family support, so that the couples prefer to use condom. Another obstacle experienced by almost all informants was the difficulty to be loyal to one partner. Almost all informants admitted that they had more than one sexual partner.

In addition to the above aspects, the cues to action aspect was also one of the predictors of behavior change in this study. Cues to action were stimulation which needed to trigger a decision-making process for health behavior (Murti, 2018). In this study, the urge to always use condoms and routinely check VCT came from within, the spouse, and the Mahardhika Style commu- 
nity. The willingness to be healthy make the informants to implement HIV/AIDS prevention behaviors such as condom use and routine VCT checks in every 3 months. In addition, the role of friends was very important in the community to encourage their members to behave well. Assistance and strengthening of healthy behavior was one of the factors that should be taken into account, because the identification results showed that community members tend to be more comfortable in conducting VCT mobile examinations held by the Mahardhika Gaya Community. This was in line with the information obtained from the Head of Mahardhika Style which stated that the focus of community activities was on health issues. Mentoring and strengthening related to health issues were the main activities of the community. Because most social cues were studied in peers, health care providers must use MSM partners to disseminate information regarding HIV prevention (Li et al,. 2016).

The final aspect in this study was selfefficacy. Self-efficacy was a person's belief about the extent to which he/she was able to control his/her motivation, behavior, and social environment which was needed to produce a behavior (Murti, 2018). All informants in this study believed that they were able to implement HIV/AIDS prevention behaviors. This belief was shown in the behavior of condom use and routine VCT checks. LI et al., (2016) stated that there was a correlation between community involvement, peers, self-efficacy and frequency of condom use. Self-efficacy was influenced by individual specific abilities and other individual factors, as well as environmental factors, both facilitating and inhibiting (Murti, 2018). Bandura (1977) mentioned that the level of motivation, feeling conditions, and actions of individuals, were more determined based on what they believe (self-efficacy) than what was objectively owned.

Knowledge of HIV/AIDS risk factors was important. The HIV/AIDS prevention behavior applied by MSM was influenced by knowledge, attitudes, perceived severity, perceived susceptibility, perceived benefits, perceived barriers, cues to action, and selfefficacy. In addition, because of the correlation between community involvement and peers in the behavior of HIV/AIDS prevention, health care providers must collaborate with MSM in disseminating information related to HIV prevention.

\section{REFERENCES}

Avert (2018). Condom - How to use a Male Condom. https://www.avert.org/sexstis/safer-sex-hiv/condoms diakses pada 26 Juli 2018.

Bandura A (1977). Self-efficacy: toward a unifying theory of behavioral change. Psychology Review. doi: 10.1016/0146-6402(78)90002-4.

Burch WJ, Hart GJ, Lim SH (2018). A qualitative study of young men who have sex with men and multilevel factors related to HIV Risk in Malaysia. AIDS Education and Prevention. doi: 10.1521/aeap.2018.30.2.85.

Centers for Disease Control and Prevention (2018). CDC fact sheet HIV among gay and bisexual men. https://www.cdc.gov/hiv/group/msm/index.html diakses pada 19 Desember 2018.

(2018). Anal Sex and HIV Risk. https://www.cdc.gov/hiv/group/msm /index.html diakses pada 19 Desember 2018.

(2018). STD risk and oral sex CDC Fact Sheet. https://www.cdc.gov/std/healthcomm/stdfact-stdriskandoralsex.htm diakses Desember 2018. 
Chittamuru, D, Icard, LD, Jemmott, JB, O'Leary A (2018). Prospective predictors of multiple sexual partners among African American men who have sex with men. Archives of Sexual Behavior, 47(7): 2081-2090. doi: 10.1007/s10508-018-1207.

Cornelisse VJ, Walker S, Philips T, Hocking JS, Bradshaw CS, Lewis DA, Prestage GP, Grulich AE, Fairley CK, Chow EPF (2018). Risk factors for oropharyngeal gonorrhoea in men who have sex with men: an Age-matched Casecontrol Study. BMJ. doi: 10.1136/sextrans-2017-053381.

Departemen of Health and Human Services (2018). Order the 9th edition of the glossary of hiv/aids-related Terms. https://aidsinfo.nih.gov/contentfiles/glossaryhivrelatedterms_english.pdf diakses pada 18 Desember 2018

Dinas Kesehatan Kota Surakarta (2018). Profil kesehatan kota Surakarta tahun 2017. http://dinkes.surakarta.go.id/profil-kesehatan-kota-surakarta-tahun-2017/ diakses Oktober 2018.

Dubov A, Galbo P, Altice FL, Fraenkel L (2018). Stigma and shame experiences by msm who take PrEP for HIV Prevention: A Qualitative Study. American Journal of Men's health. doi: $10.1177 / 1557988318797437$.

Fauk NK, Sukmawati AS, Wardojo SSI, Teli M, Bere YK, Mwanri L (2018). The intention of men who have sex with men to participate in voluntary counseling and HIV testing and access free condoms in Indonesia. American Journal of Men's Health. doi: 10.1177/1557988318779737.

Garcia MC, Duong QL, Meyer SB, Ward PR (2014). Multiple and concurrent sexual partnership among men who have sex with men in Viet Nam: Result from a National Internet-based cross-sectional survey. Health Promotion International Advance Access doi: 10.1093/heapro/dauo97.

Geary RS, Tanton C, Erens B, Clifton S, Prah P, Wellings K, Mitchel KR, Datta J, et al. (2018). Sexual identity, attraction and behaviour in Britain: The implications of using different dimensions of sexual orientation to estimate the size of sexual minority populations and inform public health interventions. Plos One. doi: 10.1371/journal.pone.0189607.

Johansson K, Persson KI, Deogan C, ElKhatib Z (2017). Factors associated with condom use and HIV Testing among young men who have sex with men: a Cross-sectional survey in random online sample in Sweeden. BMJ doi: 10.1136/sextrans-2017-053369.

Karki TB (2014). Correlation between knowledge, attitude and practice on HIV and AIDS: Cases from the Kathmandu Valley. Journal of Nepal Health Research Council. 12(1).

Kementerin Kesehatan Republik Indonesia (2014). Estimasi dan Proyeksi HIV/ AIDS di Indonesia Tahun 2011-2016. http://siha.depkes.go.id/portal/files_ upload/Estimasi_dan_Proyeksi_HIV _AIDS_di_Indonesia.pdf diakses Agustus 2018.

(2018). Data dan infomasi profil kesehatan Indonesia 2017. http://www.pusdatin.kemkes.go.id/resources/download/pusdatin/profil-kesehatan-indonesia/Data-dan-Informasi_Profil-Kesehatan-Indonesia-2017.pdf diakses pada 8 Agustus 2018.

Khumsaen N, Stephenson R (2017). Beliefs and perception about HIV/ AIDS, self-efficacy, and HIV sexual risk behaviors among young Thai men who have sex with men. AIDS Education 
and Prevention. doi: 10.1521/aeap.2017.29.2.175.

Komisi Penanggulangan AIDS Nasional (2010). Strategi dan Rencaha Aksi nasional penanggulangan HIV/AIDS 2010-2014. Kementerian koordinator bidang kesejahteraan rakyat republik indonesia.

Komisi Penanggulangan AIDS Provinsi Jawa Tengah (2018). Kondisi HIV dan AIDS di Jawa Tengah 1993 s/d 31 Desember 2015. https://www.aidsjateng.or.id/?p=halaman\&j=kpak\&s= direktori diakses pada 14 September 2018.

Li X, Lei Y, Wang H, He G, Williams AB (2016). The health belief model: a qualitative study to understand highrisk sexual behavior in Chinese men who have sex with men. Journal of The Association of Nurses in AIDS Care. 27(1). doi: 10.1016/j.jana.2015.10.005 .

Murti B (2018). Prinsip dan metode riset epidemiologi. Surakarta: Program Studi Ilmu Kesehatan Masyarakat, Program Pascasarjana, Universitas Sebelas Maret.

(2018). Teori promosi dan perilaku kesehatan. Surakarta: Program Studi Ilmu Kesehatan Masyarakat, Program Pascasarjana, Universitas Sebelas Maret.

Ong JJ, Walker S, Grulich A, Hoy J, Read TRH, Bradshaw C, Chen M, Gerland $\mathrm{SM}$, et al. (2018). Incidence, clearance and persistence of anal HPV in men who have sex with men living with HIV: implication for hpv vaccination. Wolters Kluwer. doi: 10.1097/OLQ.ooooooooooooo958.

Raymond HF, Al-Tayyib A, Alan N, Reilly $\mathrm{KH}$, Braunstein S, Brady KA, Sey E, Risser J, et al. (2017). HIV among MSM and Heterosexual Women in the
United States: An Ecologic Analysis. Journal of Acquired Immune Deficiency Syndrome. doi: 10.1097/QAI.oo00000000001422.

Siegler AJ, Voux A, Mafuya NP, Bekker LG, Sullivan PS, Baral SD, Winskell K, Kose Z, Wirtz AL, Stephenson R (2014). Elements of condom-use decision making among South African men who have sex with men. Journal of the International Assocition of Providers of AIDS Care. 13(5): 414423. doi: 10.1177/2325957414535979.

UNDP, USAID (2014). Being LGBT in Asia: Indonesia Country Report. Bangkok: UNDP.

United Nations Programme on HIV/AIDS (2018). UNAIDS Data 2018. http://www.unaids.org/sites/default/files/m edia_asset/unaids-data-2018_en.pdf dikses pada 02 Agustus 2018.

Wardhani PK, Shaluhiyah Z, Demartoto A (2015). Perilaku penggunaan kondom dan pelicin pada LSL di Kota Surakarta. Journal Promosi Kesehatan Indonesia. 10(1).

World Health Organization (2013). Male latex condom: specification, prequalification and guidelines for procurement, 2010. Departement of Reproductive Health Research Family and Community Health World Health Organization.

(2017). HIV prevention, diagnosis, treatment, and care for key populations. http://www.who.int/hiv/pub/guidelines/keypopulations/en/ diakses pada 26 Juli 2018.

(2017). Kajian Nasional Respon HIV di Bidang Kesehatan Republik Indonesia. http://www.searo.who.int/indonesia/publications/hiv_country _review_indonesia_bahasa.pdf diakses pada 4 Agustus 2018. 
Alifia et al./ Sexual Behavior for HIV Prevention among Men

(2018). Global Health Observatory (GHO) Data. http://www.who.int/gho/hiv/en/ diakses pada 26 Juli 2018.
(2018). Key Facts HIV/AIDS. http://www.who.int/news-room/factsheets/detail/hiv-aids diakses pada 26 Juli 2018. 